\title{
Phase Equilibrium Relations in the Binary System Lead Oxide-Niobium Pentoxide
}

\author{
Robert S. Roth
}

\begin{abstract}
The phase equilibrium diagram for the binary system lead oxide-niobium pentoxide has been constructed from observations of fusion characteristics and X-ray diffraction data. The system contains six binary compounds with $\mathrm{PbO}: \mathrm{Nb}_{2} \mathrm{O}_{5}$ ratios of $3: 1,5: 2$, $2: 1,3: 2,1: 1$, and $1: 2$. The compound $\mathrm{PbO} \cdot \mathrm{Nb}_{2} \mathrm{O}_{5}$ was found to melt congruently at $1,343^{\circ} \mathrm{C}$ and have a stable, reversible phase transformation temperature from the lowtemperature rhombohedral form to the high-temperature tetragonal form at $1,150^{\circ} \mathrm{C}$. The $5: 2,2: 1$, and $1: 2$ compounds melt congruently at $1,220^{\circ}, 1,233^{\circ}$, and $1,337^{\circ} \mathrm{C}$, respectively; the $3: 1$ and $3: 2$ compounds melt incongruently at $985^{\circ}$ and $1,233^{\circ} \mathrm{C}$, respectively.
\end{abstract}

\section{Introduction}

A study of phase relationships in the binary system $\mathrm{PbO}-\mathrm{Nb}_{2} \mathrm{O}_{5}$ has been conducted as part of a program of fundamental phase equilibria studies of ceramic materials. The compounds $\mathrm{PbO} \cdot \mathrm{Nb}_{2} \mathrm{O}_{5}$ and $2 \mathrm{PbO} \cdot \mathrm{Nb}_{2} \mathrm{O}_{5}$ have been previously reported by Goodman $[1],{ }^{1}$ and a phase transformation in the $\mathrm{PbO} \cdot \mathrm{Nb}_{2} \mathrm{O}_{5}$ compound has been reported by Francombe [2]. Cook and Jaffe [3, 4] have studied $2 \mathrm{PbO} \cdot \mathrm{Nb}_{2} \mathrm{O}_{5}$ and compositions deficient in $\mathrm{PbO}$ and report a cubic phase to occur at a composition of $3 \mathrm{PbO} \cdot 2 \mathrm{Nb}_{2} \mathrm{O}_{5}$. However, no systematic attempt has been made to study the phase-equilibrium relations in the entire binary system.

X-ray diffraction data, together with the determination of the melting points of the compounds and of the solidus and liquidus temperatures at various compositions across the system, have supplied data from which an equilibrium diagram has been constructed.

Because of the volatility of $\mathrm{PbO}$, many of the experiments were conducted in sealed Pt tubes. As $\mathrm{PbO}$ tends to vaporize markedly at the temperature studied, all the data may not be exactly equivalent to the true values at atmospheric pressure. However, as these experiments could not be conducted in air and the pressure inside the tube was relatively small, it is felt that the data show the best available approach to the equilibrium conditions prevailing under atmospheric pressure.

\section{Sample Preparation and Test Methods}

The following starting materials were used in the preparation of samples:

$\mathrm{PbO}$ - Reagent grade yellow lead oxide. This material was found by X-rays to contain only the high-temperature modification of $\mathrm{PbO}$, massicotite, and none of the tetragonal red lead oxide, lithargite. Spectroscopic analyses showed 0.01 to 0.1 percent Co, 0.001 to 0.01 percent $\mathrm{Bi}$ and $\mathrm{Tl}, 0.0001$ to 0.001 percent $\mathrm{Ag}, \mathrm{Al}, \mathrm{Ca}, \mathrm{Cu}$, and $\mathrm{Si}$ and less than 0.0001 percent $\mathrm{Mg}$.

\footnotetext{
1 Figures in brackets in dicate the literature references at the end of this paper.
}

$\mathrm{Nb}_{2} \mathrm{O}_{5}$ - High-purity grade niobium pentoxide, over 99.7 percent. Spectroscopic analyses showed 0.01 to 0.1 percent $\mathrm{Zr}, 0.001$ to 0.01 percent $\mathrm{Fe}$ and $\mathrm{Si}$, and 0.0001 to 0.001 percent $\mathrm{Ca}$ and $\mathrm{Mg}$.

Calculations of weight composition were made to \pm 0.01 percent, no correction being made for the percentage purity of the raw materials, except for a factor due to weight lost on ignition. The starting materials, in sufficient quantities to give a 5.0-g sample, were weighed to the nearest $0.1 \mathrm{mg}$. They were then mixed by hand, tumbled for $1 \mathrm{hr}$, ground for $1 \mathrm{hr}$ in an agate mortar, and formed into $5 / 8$-in.diam disks at a pressure of $10,000 \mathrm{lb} /$ in. $^{2}$. The pressed disks were fired for $1 \mathrm{hr}$ at $750^{\circ} \mathrm{C}$ on platinum foil in an air atmosphere, using an electricallyheated furnace wound with 80 percent Pt-20 percent Rh wire.

Following the preliminary heat treatment, the disks were ground, and for those specimens selected for the X-ray study new disks about $1 / 4$ in. high were formed at 15,000 lb/in. ${ }^{2}$ in a $1 / 2$-in.-diam mold and refired for $1 / 2$ to $1 \mathrm{hr}$ at various appropriate temperatures between $800^{\circ} \mathrm{C}$ and $1,400^{\circ} \mathrm{C}$. In order to reduce $\mathrm{PbO}$ loss, a system of inverted $\mathrm{Pt}$ crucibles similar to that reported by Jaffe, Roth, and Marzullo [5] was utilized. For those specimens which still indicated appreciable weight loss, a sealed Pt tube, containing a small amount of the ground, calcined mixture, was quenched from the appropriate temperature. Equilibrium conditions, except in the immediate vicinity of a phase transformation, could usually be obtained in the sealed tube in 10 to 15 min. X-ray diffraction powder patterns were made, using a high-angle recording Geiger-counter Spectrometer and $\mathrm{Ni}$ filtered $\mathrm{Cu}$ radiation, with the Geiger counter traversing the specimen at $1 / 40 / \mathrm{min}$ and the radiation being recorded on the chart at $1^{\circ} 2 \theta$ /in.

Specimens for solidus and liquidus determinations were mixed with a few drops of a 20 -percent solution of polyethylene glycol in water, pressed into disks in the same manner as for the X-ray specimens, and ground in the form of small four-sided pyramids grooved on each side as described by Geller et al. [6]. Solidus and liquidus determinations were made in 
the electrically heated furnace using a Pt versus $90 \mathrm{Pt}-10 \mathrm{Rh}$ thermocouple and an indicating potentiometer for temperature measurements. The specimens were placed on a $\mathrm{Pt}$ disk which was on a support of mullite. An oxidizing atmosphere existed in the furnace at all times. The specimens were placed around the circumference of a circle, 1 in. away from the thermocouple, maintained at temperature for $1 / 2 \mathrm{hr}$, and allowed to cool by shutting off the furnace. The solidus and liquidus temperatures were arrived at by visual inspection of the cooled specimen. The solidus temperature was recorded as the first sign of liquid formation, as indicated by rounding of the corners of the test pyramid. The temperature of complete melting, as indicated by the formation of a flat button, was recorded as the liquidus temperature. In all cases many tests had to be made to determine these two values.

In general, this pyramid method was only usable for those specimens containing less than 50 percent of $\mathrm{PbO}$. Specimens containing more than 50 percent of $\mathrm{PbO}$ tended to change composition rapidly when heated in air and it was necessary to seal these compositions in small $\mathrm{Pt}$ tubes. For specimens which had been heated in the sealed tubes, visual observation of partial melting of the quenched specimens could usually locate the solidus temperature. In some cases, the appearance of a new phase in the X-ray pattern with different heat treatments was the best means of locating the solidus. The liquidus temperatures could probably be found only by detailed optical microscope examination. No attempt has been made to locate accurately the liquidus temperatures in that portion of the system containing greater than 50 percent of $\mathrm{PbO}$.

The methods of determination of temperature limits of a particular phase are subject to a number of sources of error. Among these are the possible introduction of impurities into the specimens in the forming and grinding operations, the possibility of reduction of $\mathrm{Nb}_{2} \mathrm{O}_{5}$, oxidation and/or differential loss of $\mathrm{PbO}$, difference of temperature between one or more specimens and the thermocouple, and the inherent difficulty in the visual determination of the solidus and liquidus temperatures. It is believed that the temperatures as recorded are accurate to $\pm 5^{\circ} \mathrm{C}$.

\section{Compounds Involved in the $\mathrm{PbO}-\mathrm{Nb}_{2} \mathrm{O}_{5}$ System}

\section{1. $\mathrm{Nb}_{2} \mathrm{O}_{5}$}

Brauer [7] has found $\mathrm{Nb}_{2} \mathrm{O}_{5}$ to occur in three polymorphic forms. The $\mathrm{H}$-form or high-temperature form was reported as stable at temperatures above $1,200^{\circ}$ to $1,250^{\circ} \mathrm{C}$. In this study wherever free $\mathrm{Nb}_{2} \mathrm{O}_{5}$ was found, the high-temperature form was the one observed in all heated specimens, although the low-temperature form was used as the starting material. Holzberg, Reisman, Berry, and Berkenblit [8] concluded that $\mathrm{Nb}_{2} \mathrm{O}_{5}$ has only two crystalline polymorphs, the high- and the low-temperature forms, with an irreversible phase transformation, $\gamma$ to $\alpha$ (low to high) at $830^{\circ} \mathrm{C}$. They gave the parameters of the high-temperature form as, monoclinic, $a=21.34$ $\mathrm{A}, b=3.816 \mathrm{~A}, c=19.47 \mathrm{~A}$, and $\beta=120^{\circ} 20^{\prime}$. Magneli and Lagergren [9] have used the parameters $a=21.50$ A, $b=3.825 \mathrm{~A}, c=20.60 \mathrm{~A}$ and $\beta=121^{\circ} 45^{\prime}$. Holzberg et al. have indexed the diffraction peak at $1.915 \mathrm{~A}$ as $(712)$. The index of this peak should probably be (020). Holzberg [10] has agreed that the $b$ value of $3.825 \mathrm{~A}$ is probably more correct. Table 1 shows the indexed X-ray pattern of high-temperature $\mathrm{Nb}_{2} \mathrm{O}_{5}$, as found in the present study, compared with the indexed values shown by Holzberg et al. [8] and Magneli and Lagergren [9]. The parameters found for the material used in the present study are $a=$ $21.08 \mathrm{~A}, b=3.823 \mathrm{~A}, c=19.33 \mathrm{~A}$, and $\beta=119^{\circ} 48^{\prime}$.

\section{2. $\mathrm{PbO}$}

$\mathrm{PbO}$ occurs in two polymorphic forms. The lowtemperature form, stable at room temperature, is lithargite, red $\mathrm{PbO}$, tetragonal with $a=3.976 \mathrm{~A}$, $c=5.023 \mathrm{~A}$ [11]. It transforms to massicotite, yellow lead oxide, at $489^{\circ} \mathrm{C}$ [12]. Yellow $\mathrm{PbO}$ is orthorhombic, and the material used for the present study has the parameters $a=5.48 \mathrm{~A}, b=5.88 \mathrm{~A}$, $c=4.75 \mathrm{~A}$. The high-temperature polymorph is found to exist, metastably, at room temperature when quenched from any temperature in the sealed $\mathrm{Pt}$ tube. Even $65 \mathrm{hr}$ at $470^{\circ} \mathrm{C}$, just below the transformation temperature, showed no sign of red $\mathrm{PbO}$. Petersen [12] has shown that it takes two to three weeks at $420^{\circ}$ to $430^{\circ} \mathrm{C}$ to convert the yellow lead oxide into the red form.

\subsection{Compound $\mathrm{PbO} \cdot \mathrm{Nb}_{2} \mathrm{O}_{5}$}

The compound $\mathrm{PbO} \cdot \mathrm{Nb}_{2} \mathrm{O}_{5}$ has been reported to occur in four different symmetry modifications. ${ }^{2}$ The compound was first described by G. Goodman [1] as ferroelectric, orthorhombic. Francombe [2] first reported a low-temperature rhombohedral phase, and Roth [14] showed that a tetragonal modification probably also existed. Cook [15] has indicated that a pyrochlore-type phase is present if the material is not heated above $700^{\circ} \mathrm{C}$.

\section{a. Low-Temperature Rhombohedral Modification}

Francombe [2] reported that the compound $\mathrm{PbO} \cdot \mathrm{Nb}_{2} \mathrm{O}_{5}$ was polymorphic, having a phase transformation at about $1,200^{\circ}$ to $1,250^{\circ} \mathrm{C}$. The low temperature form is not ferroelectric and was reported to be rhombohedral with the "simpleststructure-cell" possessing the dimensions $a_{R}=6.206 \mathrm{~A}$ and $\alpha_{R}=58^{\circ} 18^{\prime}$. However, the X-ray powder pattern given by Francombe [2] was indexed on a larger "pseudo-cubic-cell" with dimension $a^{\prime}{ }_{R}=8.664$ $\mathrm{A}$ and $\alpha^{\prime}{ }_{R}=88^{\circ} 30^{\prime}$.

2 A paper in Russian by Efimov et al. [13] discusses the reactions involved in producing $\mathrm{PbO} \mathrm{Nb}_{2} \mathrm{O}_{5}$ and reports a face centered cubic lattice of $5.277 \mathrm{~A}$ for this producing $\mathrm{PbO} \cdot \mathrm{Nb}_{2} \mathrm{O}_{5}$ and reports a face centered cubic lattice of 5.277 A for this compound. As only an abstract of this paper was available in English, this result cannot be critically analyzed. However, it seems likely that the X-ray pattern giving rise to this data was of the pyrochlore-type structure occurring at a ratio
of $3 \mathrm{PbO}$ to $2 \mathrm{Nb}_{2} \mathrm{O}_{5}$, which has a parameter of approximately twice that given in the Russian work. 
TABLE 1. X-ray powder diffraction data for high temperature $\mathrm{Nb}_{2} \mathrm{O}_{5}$

\begin{tabular}{|c|c|c|c|c|c|c|c|c|c|c|}
\hline \multicolumn{3}{|c|}{ Magneli and Lagergren [9] } & \multicolumn{3}{|c|}{ Holzberg et al. [8] } & \multicolumn{5}{|c|}{ Present work $\mathrm{CuK}_{\alpha_{1}}$ radiation } \\
\hline$d_{\mathrm{obs}}$ & $I / I_{0}$ & $h k l^{\mathrm{a}}$ & $d_{\text {obs }}$ & $I / I_{0}$ & $h k l^{\mathrm{b}}$ & $d$ & $I / I_{0}$ & $1 / d_{\text {obs }}^{2}$ & $1 / d_{\mathrm{aalo}}^{2}{ }^{\circ}$ & $h k l \mathrm{~d}$ \\
\hline $\begin{array}{l}17.0 \\
10.6\end{array}$ & $\begin{array}{l}30 \\
40\end{array}$ & $\begin{array}{r}10 \overline{1} / 001 \\
201\end{array}$ & $\begin{array}{l}16.9 \\
10.6\end{array}$ & $\begin{array}{l}10 \\
20\end{array}$ & $\begin{array}{l}001 \\
201\end{array}$ & $\begin{array}{l}16.66 \\
10.517\end{array}$ & $\begin{array}{l}6 \\
5\end{array}$ & $\begin{array}{r}0.0036 \\
.0090\end{array}$ & $\begin{array}{l}0.0036 \\
0090\end{array}$ & 001 \\
\hline & & & & & & 10.063 & 2 & .0099 & .0099 & 101 \\
\hline $\begin{array}{l}9.7 \\
9.2\end{array}$ & $\begin{array}{l}10 \\
20\end{array}$ & $\begin{array}{l}102 \\
000\end{array}$ & 9.7 & $\begin{array}{r}10 \\
-10\end{array}$ & $10 \overline{2}$ & 9.615 & 2 & .0108 & .0107 & $10 \overline{2}$ \\
\hline & & & & & & 9.148 & & & .0120 & 200 \\
\hline 8.5 & 20 & 002 & 8.4 & $<10$ & 002 & 8. 354 & 4 & .0143 & .0142 & 002 \\
\hline -..-- & -..-. & -...-..- & -...-. & -..... & -.. & 6. 942 & 2 & .0208 & .0207 & 301 \\
\hline 6.35 & 30 & $10 \overline{3}$ & 6.32 & 10 & $10 \overline{3}$ & $\begin{array}{l}6.486 \\
6.285\end{array}$ & $\begin{array}{r}3 \\
11\end{array}$ & .0238 & .0237 & $\begin{array}{l}102 \\
10 \overline{3}\end{array}$ \\
\hline 5.60 & 10 & 003 & 5. 60 & $<10$ & 003 & 5. 590 & 4 & .0320 & .0320 & 003 \\
\hline 5. 30 & 10 & $40 \overline{2}$ & 5. 29 & $<10$ & $40 \overline{2}$ & 5. 273 & 6 & .0360 & .0361 & $40 \overline{2}$ \\
\hline 5.15 & 60 & 401 & 5. 13 & 20 & 401 & 5.116 & 48 & .0382 & .0384 & 401 \\
\hline & & & & $<10$ & 103 & 4. 734 & 4 & .0446 & .0447 & 103 \\
\hline 4.63 & 50 & 104 & 4. 63 & 20 & 104 & $\begin{array}{l}\text { 4. } 616 \\
3.852\end{array}$ & 36 & .0469 & .0469 & $10 \overline{4}$ \\
\hline & & & & & & & & & . & \\
\hline 3.83 & 20 & $\begin{array}{l}205 \\
010\end{array}$ & 3. 83 & $<10$ & 010 & 3. 821 & 6 & .0685 & $\left\{\begin{array}{l}.0684 \\
.0684\end{array}\right.$ & $\begin{array}{l}010 \\
205\end{array}$ \\
\hline 3.75 & 100 & 110 & $\begin{array}{l}3.75 \\
3.74\end{array}$ & $\begin{array}{l}70 \\
50\end{array}$ & $\begin{array}{l}40 \overline{5} \\
110\end{array}$ & 3. 737 & 100 & .0716 & $\begin{array}{l}.0714 \\
.0717\end{array}$ & 110 \\
\hline 3.65 & 100 & $10 \overline{5}$ & 3. 65 & 100 & $10 \overline{5}$ & 3.636 & 100 & 0756 & $\begin{array}{l}.0719 \\
.0757\end{array}$ & $\begin{array}{l}405 \\
105\end{array}$ \\
\hline 3.59 & 10 & 111 & 3.56 & $<10$ & 111 & $\begin{array}{l}3.050 \\
3.577\end{array}$ & 4 & .0782 & .0782 & $\begin{array}{l}105 \\
111\end{array}$ \\
\hline 3.56 & 20 & $11 \overline{2}$ & - & 0 & $11 \overline{2}$ & 3.553 & 4 & .0792 & .0791 & $11 \overline{2}$ \\
\hline -..... & -...... & .... & - - & -...... & -... & 3.515 & 4 & .6809 & .0804 & 210 \\
\hline -..... & ....... & -.... & ....... & -..... & -..- & -....- & (n..... & (...... & .0812 & 603 \\
\hline -...... & - & $60 \overline{3}$ & . & ....... & & - & & 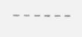 & .0816 & $21 \overline{2}$ \\
\hline 3.49 & 100 & $\begin{array}{l}602 \\
012\end{array}$ & 3. 49 & 50 & $21 \overline{2}$ & 3. 483 & 100 & .0824 & $\left\{\begin{array}{l}.0826 \\
.0826\end{array}\right.$ & $\begin{array}{l}50 \overline{5} \\
012\end{array}$ \\
\hline -.... & -....... & - & -..... & - - & .... & - & ....... & - & .0829 & $60 \overline{2}$ \\
\hline 3.41 & 10 & $60 \overline{4}$ & 3. 41 & $<10$ & $60 \overline{4}$ & 3. $4 \mathrm{C} 6$ & 4 & .0862 & .0867 & $60 \overline{4}$ \\
\hline & & & & 0 & 402 & 3. 383 & 4 & .0874 & .0879 & 402 \\
\hline 3.36 & 60 & $005 / 31 \overline{1}$ & 3. 36 & 10 & 005 & 3.351 & 28 & . 8891 & $\begin{array}{r}.0889 \\
.0891\end{array}$ & $\begin{array}{l}005 \\
311\end{array}$ \\
\hline 3.32 & 20 & $60 \overline{1}$ & 3. 32 & $<10$ & 211 & 3. 316 & 5 & . 0909 & $\begin{array}{l}.0904 \\
.0917\end{array}$ & 211 \\
\hline -..... & -.... & -.... & 3. 28 & $<10$ & $21 \overline{3}$ & -...- & - & -.... & .0917 & $21 \overline{3}$ \\
\hline 3. 27 & 20 & $11 \overline{3}$ & - & 0 & $11 \overline{3}$ & 3. 264 & 4 & .0939 & .0937 & $11 \overline{3}$ \\
\hline 3.17 & $40^{-}$ & 013 & 3.17 & $<10$ & $20 \overline{\overline{6}}$ & $\begin{array}{l}3.247 \\
\text { 3.153 }\end{array}$ & $\begin{array}{r}4 \\
11\end{array}$ & $\begin{array}{l}.0949 \\
.1006\end{array}$ & $\begin{array}{l}.0948 \\
.1004\end{array}$ & $\begin{array}{l}204 \\
013\end{array}$ \\
\hline & & & & & & & & & .1045 & $41 \overline{2}$ \\
\hline 3.09 & 20 & $50 \overline{6}$ & 3. 09 & $<10$ & $41 \overline{2}$ & 3. 078 & 6 & .1055 & .1055 & $50 \overline{6}$ \\
\hline 3.00 & 30 & $10 \overline{6}$ & 3. 01 & $<10$ & $10 \overline{6}$ & 2. 994 & 7 & .1116 & $\{.1113$ & $21 \overline{4}$ \\
\hline 2.95 & 10 & $11 \frac{214}{114}$ & ....... & ...... & .... & ....... & $\ldots$ & .1110 & $\begin{array}{ll}.1116 \\
.1153\end{array}$ & $\begin{array}{l}106 \\
114\end{array}$ \\
\hline 2. 84 & 90 & $\begin{array}{l}51 \overline{2} \\
014\end{array}$ & 2. 84 & 10 & $51 \overline{2}$ & 2. 832 & 36 & .1247 & .1249 & $51 \overline{2}$ \\
\hline 2.82 & 10 & $51 \frac{4}{3}$ & 2. 83 & 10 & $70 \overline{1}$ & 2. 826 & 38 & .1252 & .1253 & 014 \\
\hline -.-.- & -...- & -... & & 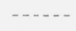 & & - - & $\cdots$ & -..... & .1265 & $51 \frac{1}{3}$ \\
\hline -..... & - & .... & - & - . & ... & - & - & ........ & .1273 & $70 \overline{1}$ \\
\hline 2.77 & 80 & $51 \overline{1}$ & 2. 78 & 20 & $51 \overline{1}$ & 2. 771 & 31 & .1303 & $\left\{\begin{array}{l}.1305 \\
1306\end{array}\right.$ & $51 \overline{1}$ \\
\hline 2. 73 & 10 & $51 \overline{4}$ & & & & & & & .1352 & $51 \frac{1}{4}$ \\
\hline $\begin{array}{l}2.70 \\
0\end{array}$ & 80 & ${ }_{706}^{215}$ & 2. 71 & 20 & $21 \overline{5}$ & 2. 701 & 34 & .1371 & .1369 & 215 \\
\hline 2.70 & 10 & 706 & (n) & - & .... & -.... & - & - & .1383 & $70 \overline{6}$ \\
\hline 2. 67 & 10 & $41 \overline{5}$ & 2. 677 & $<10$ & 415 & 2. 668 & 3 & .1405 & $\left\{\begin{array}{l}.1403 \\
.1408\end{array}\right.$ & 415 \\
\hline 2.65 & 20 & 510 & ...... & & 201 & 2. 644 & 4 & .1431 & $\begin{array}{r}1408 \\
.1431\end{array}$ & $\begin{array}{l}207 \\
510\end{array}$ \\
\hline 98 & 20 & $80^{\overline{3}}$ & 2825 & $<1$ & & & 5 & & .1441 & $11 \overline{5}$ \\
\hline 2. 63 & 20 & 803 & 2.635 & $<10$ & 115 & 2. 628 & 5 & .1448 & .1444 & $80 \frac{4}{2}$ \\
\hline 2. 58 & 10 & $51 \overrightarrow{5}$ & & & & & & & $\begin{array}{l}.1454 \\
.1510\end{array}$ & $\begin{array}{l}803 \\
515\end{array}$ \\
\hline & & $\begin{array}{l}612 \\
802\end{array}$ & & & & & & & $\begin{array}{l}.1513 \\
.1536\end{array}$ & $\begin{array}{l}61 \overline{2} \\
80 \overline{2}\end{array}$ \\
\hline 2. 54 & 70 & $\begin{array}{l}61 \overline{4} \\
503\end{array}$ & 2. 549 & 10 & $10 \overline{7}$ & 2. 543 & 36 & .1546 & $\begin{array}{r}.1545 \\
.1551\end{array}$ & 107 \\
\hline 2. 53 & 10 & 412 & 2. 537 & $<10$ & 503 & $\ldots$ & 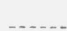 & - & .1553 & 503 \\
\hline -..-. & -...- & -.... & & 0 & 404 & -..-. & - & -... & .1564 & 412 \\
\hline ....... & $-\cdots$ & ..... & ----- & 0 & 412 & -..- & - & -..-- & .1565 & 313 \\
\hline 2.53 & 30 & 015 & 2. 529 & $<10$ & 313 & 2. 523 & 5 & .1571 & $\begin{array}{l}.1565 \\
.1573\end{array}$ & $\begin{array}{l}404 \\
015\end{array}$ \\
\hline 2. 49 & 50 & $70 \overline{7}$ & 2. 496 & 10 & $80 \overline{6}$ & 2. 491 & 26 & .1612 & . 1619 & $70 \overline{7}$ \\
\hline 2.48 & 30 & 214 & 2. 483 & $<10$ & 511 & 2. 478 & 8 & .1629 & $\left\{\begin{array}{l}.1629 \\
.1632\end{array}\right.$ & $\begin{array}{l}511 \\
214\end{array}$ \\
\hline & & & & & & & & & .1637 & $80 \frac{6}{6}$ \\
\hline 2.45 & 20 & $41 \overline{\bar{b}}$ & 2. 457 & & $61 \overline{5}$ & 2. 452 & 5 & .1664 & . 1665 & $41 \overline{6}$ \\
\hline & & & & & & & & 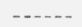 & . 1688 & 801 \\
\hline
\end{tabular}

See footnotes at end of table. 
TABLE 1. X-ray powder diffraction data for high temperature $\mathrm{Nb}_{2} \mathrm{O}_{5}-$ Continued

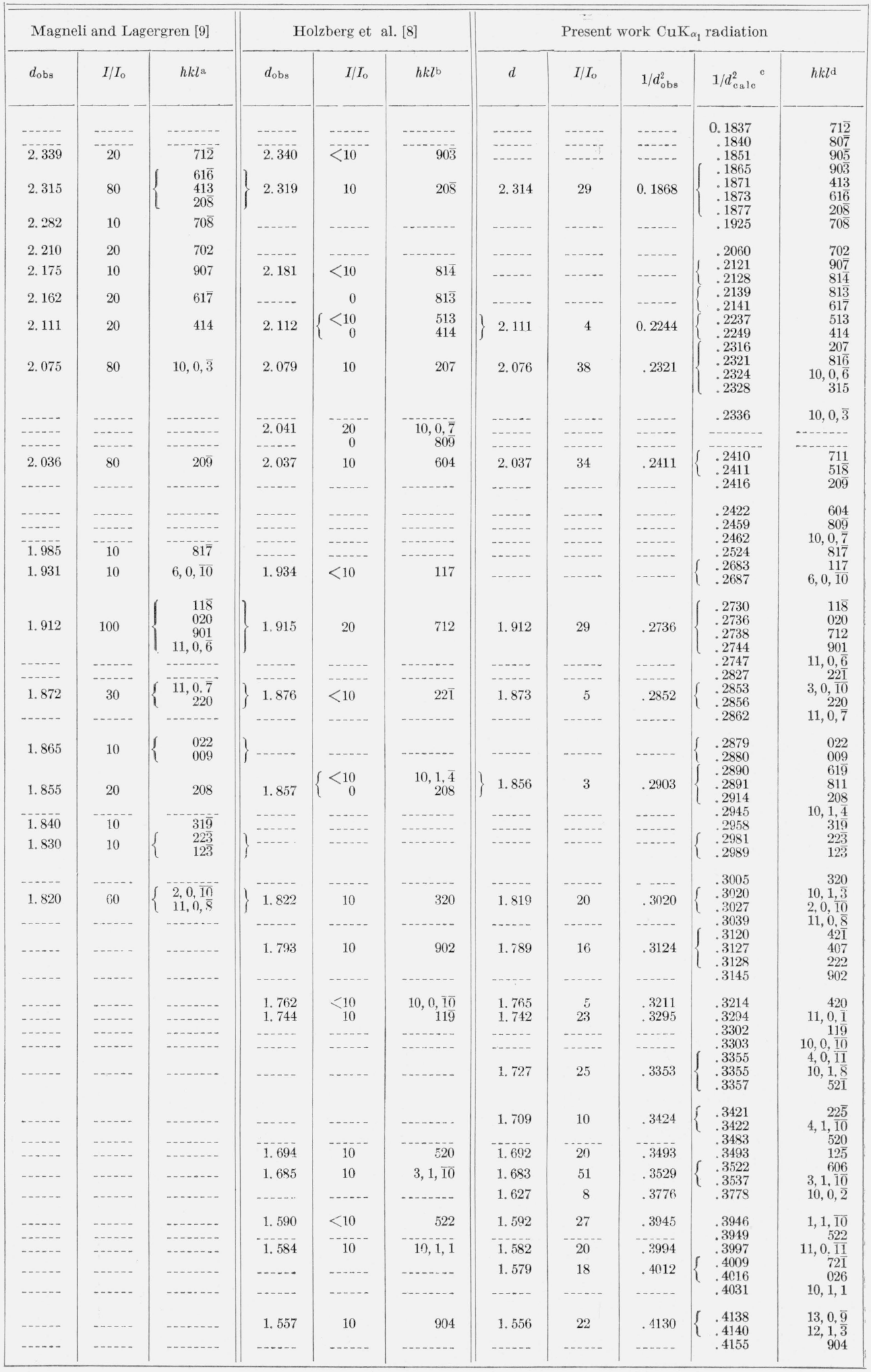

a The parameters upon which these $h k l$ values are based are $a=21.50 \mathrm{~A}, b=3.825 \mathrm{~A}, c=20.60 \mathrm{~A}, \boldsymbol{\beta}=121^{\circ} 45^{\prime}$.

b The parameters upon whjch these $h k l$ values are based are $a=21.34 \mathrm{~A}, b=3.816 \mathrm{~A}, c=19.47 \mathrm{~A}, \beta=120^{\circ} 20^{\circ}$.

- Only those values are listed which were either found as peaks in the present study or roported as peaks by previous workers.

d The parameters upon which these $h k l$ values are based are $a=21.08 \mathrm{~A}, b=3.823 \mathrm{~A}, c=19,33 \mathrm{~A}, \beta=119^{\circ} 48^{\prime}$. 
It can easily be seen that the larger "pseudo-cell" is related to the smaller "simplest-cell" by a doubling of the hexagonal $a$ axis. For the "simplest-cell" $a_{H}=6.04 \mathrm{~A}, c_{H}=15.394 \mathrm{~A}$ and for the "pseudo-cell" $a_{H}=12.093 \mathrm{~A}, \quad c_{H}=15.394 \mathrm{~A}$. The pattern was indexed by Francombe using hexagonal $h k l$ values for the larger cell. However, a simple examination of this indexing reveals that many of the $h k l$ values used are not allowed by a rhombohedral cell, where $h-k+l=3 n$. Furthermore, the observed versus calculated $d$ spacings do not fit for many of the lines. The same observations are true for the "simplestcell."

Cook [15] has given the rhombohedral unit cell of the low-temperature form of $\mathrm{PbO} \cdot \mathrm{Nb}_{2} \mathrm{O}_{5}$ as $a_{R}=$ $7.168 \mathrm{~A}$ and $\alpha_{R}=93^{\circ} 52^{\prime}$. These parameters correspond to a bexagonal unit cell of $a=10.473 \mathrm{~A}$ and $c=11.549 \mathrm{~A}$. This cell is related to Francombe's "simplest-cell" by a multiplication and rotation of the unit-cell parameters of the hexagonal cell:

$$
\begin{aligned}
& a_{H}(\text { Cook })=\sqrt{3} a_{H} \text { (Francombe), } \\
& c_{H}(\text { Cook })=3 / 4 c_{H} \text { (Francombe). }
\end{aligned}
$$

An X-ray powder pattern of the rhombohedral form of $\mathrm{PbO} \cdot \mathrm{Nb}_{2} \mathrm{O}_{5}$, indexed on the basis of the cell suggested by Cook, is shown in table 2. The unit-cell parameters of this material are found to be $a_{R}=$ $7.184 \mathrm{~A}, \alpha_{R}=93^{\circ} 55^{\prime} ; a_{H}=10.510 \mathrm{~A}, c_{H}=11.562 \mathrm{~A}$.

\section{b. Metastable Orthorhombic Ferroelectric Modification}

The orthorhombic modification was the first form of $\mathrm{PbO} \cdot \mathrm{Nb}_{2} \mathrm{O}_{5}$ to be reported. It was discovered to be ferroelectric by G. Goodman [1] who reported an orthorhombic unit cell having the approximate dimensions $a=25 \mathrm{~A}, b=25 \mathrm{~A}, c=7.0 \mathrm{~A}$. Francombe [2] found that the ferroelectric form only occurred when the specimen had been heated above the phase transformation temperature of $1,200^{\circ}$ to $1,250^{\circ} \mathrm{C}$. He reported this form to be orthorhombic with $a=17.51 \mathrm{~A}, b=17.81 \mathrm{~A}, c=7.73 \mathrm{~A}$. In a previous publication arising from the present work [14] the $\mathrm{X}$-ray powder diffraction pattern of the ferroelectric modification of $\mathrm{PbO} \cdot \mathrm{Nb}_{2} \mathrm{O}_{5}$ was indexed on the basis of an orthorhombic unit cell with $a=17.63 \mathrm{~A}$, $b=17.93 \mathrm{~A}, c=3.868 \mathrm{~A}$. Long film exposures using single-crystal techniques have shown that the true unit cell actually has a $c$ axis value of twice that given [15]. This larger value does not show up in a Geiger counter tracing of the powder diffraction pattern. It has been shown [14] that the ferroelectric modification is only metastable, reverting to the rhombohedral form if heated several times from room temperature to $700^{\circ} \mathrm{C}$. It, therefore, has no field of stability in the binary system $\mathrm{PbO}-\mathrm{Nb}_{2} \mathrm{O}_{5}$.

\section{c. High-Temperature Tetragonal Modification}

Goodman [1] added small amounts of $\mathrm{ZrO}_{2}$ and/or $\mathrm{TiO}_{2}$ to his materials in order to obtain dense ceramics. Roth [14] has shown that the addition of such impurities has the effect of producing the
TABLE 2. X-ray diffraction powder data for low temperature,

\begin{tabular}{|c|c|c|c|c|c|}
\hline$d$ & $I / I_{0}$ & $1 / d_{\mathrm{obs}}^{2}$ & $1 / d_{\mathrm{calc}}^{2}{ }^{\mathrm{a}}$ & $\begin{array}{c}\text { Rhombo- } \\
\text { hedral }\end{array}$ & Hexagonal \\
\hline $\begin{array}{l}\text { 7. } 184 \\
\text { 5. } 270 \\
\text { 4. } 889 \\
\text { 4. } 231 \\
\text { 3. } 109\end{array}$ & $\begin{array}{r}5 \\
13 \\
3 \\
7 \\
100\end{array}$ & $\begin{array}{r}0.0194 \\
.0360 \\
.0418 \\
.0559 \\
.1035\end{array}$ & $\begin{array}{r}0.0196 \\
.0363 \\
.0420 \\
.0558 \\
.1036\end{array}$ & $\begin{array}{c}h k l \\
010 \\
011 \\
110 \\
111 \\
120\end{array}$ & $\begin{array}{c}h k l \\
011 \\
110 \\
102 \\
201 \\
113\end{array}$ \\
\hline $\begin{array}{l}\text { 3. } 034 \\
\text { 2. } 957 \\
\text { 2. } 626 \\
\text { 2. } 383 \\
\text { 2. } 170\end{array}$ & $\begin{array}{r}100 \\
10 \\
11 \\
7 \\
69\end{array}$ & $\begin{array}{r}.1086 \\
.1144 \\
.1450 \\
.1760 \\
.2123\end{array}$ & $\begin{array}{l}.1088 \\
.1146 \\
.1451 \\
.1761 \\
.2124\end{array}$ & $\begin{array}{c}11 \overline{2} / \overline{1} 2 \overline{1} \\
12 \overline{1} \\
022 \\
030 / 22 \overline{1} \\
13 \overline{1}\end{array}$ & $\begin{array}{l}300 \\
212 \\
220 \\
033 \\
223\end{array}$ \\
\hline $\begin{array}{l}\text { 2. } 116 \\
\text { 2. } 061 \\
\text { 2. } 054 \\
\text { 1. } 9840 \\
\text { 1. } 9270\end{array}$ & $\begin{array}{r}6 \\
5 \\
10 \\
48 \\
9\end{array}$ & $\begin{array}{l}.2233 \\
.2353 \\
.2371 \\
.2541 \\
.2693\end{array}$ & $\begin{array}{l}.2234 \\
.2354 \\
.2372 \\
.2539 \\
.2693\end{array}$ & $\begin{array}{c}22 \overline{2} \\
131 \\
03 \overline{2} \\
12 \overline{3} / 13 \overline{2} \\
222\end{array}$ & $\begin{array}{l}402 \\
025 \\
231 \\
410 \\
006\end{array}$ \\
\hline $\begin{array}{l}\text { 1. } 9012 \\
\text { 1. } 8093 \\
\text { 1. } 7964 \\
\text { 1. } 7640 \\
\text { 1. } 7502\end{array}$ & $\begin{array}{r}5 \\
10 \\
8 \\
100 \\
58\end{array}$ & $\begin{array}{r}.2767 \\
.3055 \\
.3099 \\
.3214 \\
.3265\end{array}$ & $\begin{array}{l}.2769 \\
.3056 \\
.3097 \\
.3212 \\
.3264\end{array}$ & $\begin{array}{c}23 \overline{1} \\
23 \overline{1} \\
22 \overline{3} \\
04 \overline{1} / 23 \overline{2} \\
03 \overline{3}\end{array}$ & $\begin{array}{l}314 \\
116 \\
501 \\
143 \\
330\end{array}$ \\
\hline $\begin{array}{l}\text { 1. } 6477 \\
\text { 1. } 6263\end{array}$ & $\begin{array}{r}4 \\
40\end{array}$ & $\begin{array}{l}.3683 \\
.3781\end{array}$ & $\begin{array}{l}.3685 \\
.3781\end{array}$ & $\begin{array}{c}04 \overline{2} \\
141 / 330\end{array}$ & $\begin{array}{l}242 \\
036\end{array}$ \\
\hline 1. 5530 & 7 & .4146 & $\begin{array}{l}.4144 \\
.4149\end{array}$ & $\begin{array}{l}240 \\
331\end{array}$ & $\begin{array}{l}226 \\
207\end{array}$ \\
\hline $\begin{array}{l}\text { 1. } 5156 \\
\text { 1. } 3826\end{array}$ & $\begin{array}{l}22 \\
10\end{array}$ & $\begin{array}{l}.4353 \\
.5231\end{array}$ & $\begin{array}{l}.4353 \\
.5232\end{array}$ & $\begin{array}{l}22 \overline{4} / 24 \overline{2} \\
150 / 341\end{array}$ & $\begin{array}{l}600 \\
146\end{array}$ \\
\hline $\begin{array}{l}\text { 1. } 3620 \\
\text { 1. } 3483 \\
\text { 1. } 3360 \\
\text { 1. } 3336 \\
\text { 1. } 3126\end{array}$ & $\begin{array}{r}18 \\
20 \\
5 \\
5 \\
13\end{array}$ & $\begin{array}{l}.5391 \\
.5501 \\
.5603 \\
.5623 \\
.5804\end{array}$ & $\begin{array}{l}.5389 \\
.5498 \\
.5600 \\
.5618 \\
.5803\end{array}$ & $\begin{array}{c}05 \overline{2} / 24 \overline{3} \\
15 \overline{2} \\
151 \\
34 \overline{2} \\
044\end{array}$ & $\begin{array}{l}253 \\
162 \\
047 \\
515 \\
440\end{array}$ \\
\hline $\begin{array}{l}\text { 1. } 2955 \\
\text { 1. } 2542 \\
\text { 1. } 2481 \\
\text { 1. } 2425 \\
\text { 1. } 1912\end{array}$ & $\begin{array}{r}22 \\
6 \\
5 \\
4 \\
11\end{array}$ & $\begin{array}{r}.5958 \\
.6357 \\
.6420 \\
.6478 \\
.7047\end{array}$ & $\begin{array}{l}.5957 \\
.6359 \\
.6422 \\
.6477 \\
.7046\end{array}$ & $\begin{array}{c}25 \overline{1} \\
251 \\
34 \overline{2} \\
15 \overline{3} \\
060 / 44 \overline{2}\end{array}$ & $\begin{array}{l}336 \\
138 \\
119 \\
443 \\
066\end{array}$ \\
\hline $\begin{array}{l}\text { 1. } 1613 \\
\text { 1. } 1536 \\
\text { 1. } 1493 \\
\text { 1. } 1421\end{array}$ & $\begin{array}{r}7 \\
6 \\
100 \\
8\end{array}$ & $\begin{array}{r}.7415 \\
.7514 \\
.7571 \\
.7666\end{array}$ & $\begin{array}{l}.7414 \\
.7510 \\
.7565 \\
.7674\end{array}$ & $\begin{array}{c}160 \\
3 \frac{351}{34 / 162} \\
154\end{array}$ & $\begin{array}{l}157 \\
229 \\
713 \\
542\end{array}$ \\
\hline 1. 1314 & 4 & .7812 & $\begin{array}{r}.7810 \\
.7813\end{array}$ & $\begin{array}{l}161 \\
335\end{array}$ & $\begin{array}{l}058 \\
801\end{array}$ \\
\hline $\begin{array}{l}\text { 1. } 1067 \\
\text { 1. } 0958 \\
\text { 1. } 0846 \\
\text { 1. } 0782\end{array}$ & $\begin{array}{r}6 \\
5 \\
12 \\
28\end{array}$ & $\begin{array}{l}.8165 \\
.8328 \\
.8501 \\
.8602\end{array}$ & $\begin{array}{l}.8157 \\
.8327 \\
.8496 \\
.8598\end{array}$ & $\begin{array}{c}35 \overline{3} \\
352 \\
26 \overline{2} \\
261 / 450\end{array}$ & $\begin{array}{c}625 \\
1,2,10 \\
446 \\
149\end{array}$ \\
\hline
\end{tabular}
rhombohedral $\mathrm{PbNb}_{2} \mathrm{O}_{6}\left(\mathrm{CuK}_{\alpha_{1}}\right.$ Radiation $)$

a These values are based on the unit-cell parameters $a_{H}=10.501 \mathrm{~A}, c_{H}=11.562$ $\mathrm{A}, a_{R}=7.184 \mathrm{~A}, \alpha_{R}=93^{\circ} 55^{\prime}$.

orthorhombic structure in a form apparently stable at room temperature regardless of further heat treatments in laboratory time. A solid solution, of $\mathrm{PbO} \cdot \mathrm{Nb}_{2} \mathrm{O}_{5}$ plus 2 weight percent of $\mathrm{ZrO}_{2} \cdot \mathrm{TiO}_{2}$, was examined by high-temperature X-rays at $600^{\circ} \mathrm{C}$, above the ferroelectric Curie point. The resulting pattern could be indexed on the basis of a tetragonal unit cell with $a=12.56 \mathrm{~A}$ and $c=3.925 \mathrm{~A}$ [14]. It is still not known whether the $c$ axis should be doubled for the true tetragonal cell.

High-termperature X-ray patterns made in this laboratory, indicate that pure $\mathrm{PbO} \cdot \mathrm{Nb}_{2} \mathrm{O}_{5}$ has tetragonal symmetry, as a stable modification, from the temperature of the high-low phase transformation to the melting point. If the hightemperature modification is cooled quickly below the transformation point, it will maintain the tetragonal structure in a metastable condition. When it reaches the Curie point, reported as $590^{\circ} \mathrm{C}$ by Goodman [1], it transforms metastably and reversibly to the orthorhombic ferroelectric modification. 


\section{d. Pyrochlore-Type Modification}

Cook $[15]$ has claimed that another low-temperature form of $\mathrm{PbO} \cdot \mathrm{Nb}_{2} \mathrm{O}_{5}$ exists below $700^{\circ} \mathrm{C}$ and that it "appears to be a pyrochlore structure previously unreported for lead niobate of this formula." Examination of the X-ray pattern of $\mathrm{PbO} \cdot \mathrm{Nb}_{2} \mathrm{O}_{5}$ heated at $550^{\circ} \mathrm{C}$ for $16 \mathrm{hr}$ as well as that of a specimen supplied by Cook, showed that the pyrochloretype phase reported actually was $3 \mathrm{PbO} \cdot 2 \mathrm{Nb}_{2} \mathrm{O}_{5}$, and that rhombohedral $\mathrm{PbO} \cdot \mathrm{Nb}_{2} \mathrm{O}_{5}$ and free $\mathrm{Nb}_{2} \mathrm{O}_{5}$ also were present. It can therefore be concluded that $\mathrm{PbO} \cdot \mathrm{Nb}_{2} \mathrm{O}_{5}$ does not form a pyrochlore-type structure under any conditions.

\subsection{Compound $2 \mathrm{PbO} \cdot \mathrm{Nb}_{2} \mathrm{O}_{5}$}

The compound $2 \mathrm{PbO} \cdot \mathrm{Nb}_{2} \mathrm{O}_{5}$ has been studied by Cook and Jaffe [3,4], Shirane and Pepinsky [17], Hulm [18], and Jona, Shirane, and Pepinsky [19]. Cook and Jaffe [3] list the compound $2 \mathrm{PbO} \cdot \mathrm{Nb}_{2} \mathrm{O}_{5}$ as rhombohedral with $a=5.285 \mathrm{~A}$ and $\alpha=89^{\circ} 15^{\prime}$. They later [4] imply that the $a$ axis should be doubled, thus suggesting a rhombohedral distortion of the pyrochlore-type structure. Jona, Shirane, and Pepinsky [19] give values of $a=10.674 \mathrm{~A}$, $\alpha=88^{\circ} 50^{\prime}$. The values obtained in the present study are $a=10.676 \mathrm{~A}, \alpha=88^{\circ} 44^{\prime}$, and the indexed X-ray diffraction pattern is given in table 3 . Shirane and Pepinsky [17] and Hulm [18] have shown a dielectric anomaly in $2 \mathrm{PbO} \cdot \mathrm{Nb}_{2} \mathrm{O}_{5}$ at about $14^{\circ} \mathrm{K}$, indicating a phase transformation, but nothing is known of the structure of this phase.

\subsection{Compound $3 \mathrm{PbO} \cdot 2 \mathrm{Nb}_{2} \mathrm{O}_{5}$}

Cook and Jaffe [4] reported the observation of a cubic pyrochlore-type phase at approximately "the composition $\mathrm{Pb}_{1.5} \mathrm{Nb}_{2} \mathrm{O}_{6.5}$ " but did not definitely call it a compound. They observed a unit-cell parameter for this composition of $10.561 \mathrm{~A}$. In the present study this phase has been identified as a compound with little or no solid solution, of the composition $3 \mathrm{PbO} \cdot 2 \mathrm{Nb}_{2} \mathrm{O}_{5}$. It has been found to melt incongruently at $1,233^{\circ} \mathrm{C}$ to liquid plus $\mathrm{PbO} \cdot \mathrm{Nb}_{2} \mathrm{O}_{5}$.

\subsection{Compound $5 \mathrm{PbO} \cdot 2 \mathrm{Nb}_{2} \mathrm{O}_{5}$}

This compound has not been previously reported. It was discovered in the present work by observing that compositions in the area containing a single-phase rhombohedral pyrochlore-type structure did not begin melting at temperatures to be expected from a simple solid-solution region. It was obvious that a new compound of approximately the ratio $5: 2 \mathrm{had}$ to be introduced in order to explain the meltingpoint data. This composition containing 71.43 mole percent of $\mathrm{PbO}$ is the high $\mathrm{PbO}$ end member of this solid-solution series. The composition containing 72 mole percent of $\mathrm{PbO}$ shows some of the compound $3 \mathrm{PbO} \cdot \mathrm{Nb}_{2} \mathrm{O}_{5}$. The compound $5 \mathrm{PbO} \cdot 2 \mathrm{Nb}_{2} \mathrm{O}_{5}$ apparently has the same symmetry as the $2: 1$ compound, probably rbombohedral. The $5: 2$ compound shows a larger distortion from the ideal cubic pyrochlore-type structure than does the compound
TABLE 3. X-ray diffraction powder data for rhombohedral $2 \mathrm{PbO} \cdot \mathrm{Nb}_{2} \mathrm{O}_{5}\left(\mathrm{CuK} \alpha_{1}\right.$ radiation $)$

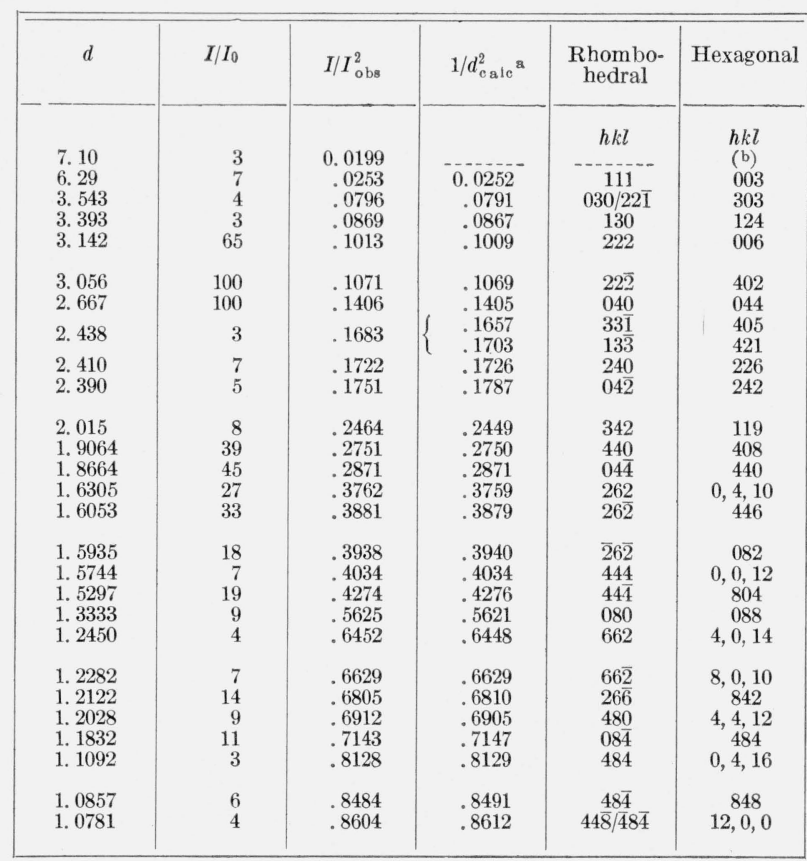

s These values are based on the unit-cell parameters

$$
a_{H}=14.931 \mathrm{~A}, c_{H}=18.893 \mathrm{~A}, a_{R}=10.676 \mathrm{~A}, \alpha=88^{\circ} 44^{\prime} .
$$

b This peak does not fit the proposed rhombohedral structure, but it is reproducible and apparently indicates a lower symmetry for the true structure of $2 \mathrm{PbO} \cdot \mathrm{Nb}_{2} \mathrm{O}_{5}$. Such a peak also occurs in the patterns of the compound $5 \mathrm{PbO} \cdot 2 \mathrm{Nb}_{2} \mathrm{O}_{5}$ and the solid solutions between the two.

$2 \mathrm{PbO} \cdot \mathrm{Nb}_{2} \mathrm{O}_{5}$. The parameters observed for the $5: 2$ compound are $a_{R}=10.709 \mathrm{~A} ; \alpha_{R}=88^{\circ} 14^{\prime}$.

The composition of the $5: 2$ compound can be arrived at by analogy to the pyrochlore-type structure. The theoretical cubic pyrochlore-type structure contains $16 \mathrm{~A}$ ions, $16 \mathrm{~B}$ ions, and 56 negative ions. Of the negative ions, 48 occupy one set of equivalent positions and 8 ions occupy another. In the $\mathrm{PbO} \cdot \mathrm{Nb}_{2} \mathrm{O}_{5}$ system a unique compound is formed at a ratio of $1 \frac{1}{2} \mathrm{~Pb}^{+2}$ ions to $2 \mathrm{Nb}^{+5}$ ions or $\mathrm{Pb}_{1.5} \mathrm{Nb}_{2} \mathrm{O}_{6.5} \quad\left(\mathrm{~Pb}_{12} \mathrm{Nb}_{16} \mathrm{O}_{48} \mathrm{O}_{4}\right)$. On the high- $\mathrm{PbO}$ side of the pyrochlore-type formula a likely compound is one in which 8 oxygen ions are missing, those belonging to the 8-fold equivalent position. This type of compound would be $\mathrm{Pb}_{2} \mathrm{Nb}_{1.6} \mathrm{O}_{6}\left(\mathrm{~Pb}_{16} \mathrm{Nb}_{12.8} \mathrm{O}_{48}\right)$ which has a $\mathrm{PbO}: \mathrm{Nb}_{2} \mathrm{O}_{5}$ ratio of $5: 2$. This composition is observed to be the high- $\mathrm{PbO}$ end of the solid solution series.

\subsection{Compound $3 \mathrm{PbO} \cdot \mathrm{Nb}_{2} \mathrm{O}_{5}$}

The compound $3 \mathrm{PbO} \cdot \mathrm{Nb}_{2} \mathrm{O}_{5}$ has also not been previously reported. It has a distorted pyrochloretype structure which resembles $2 \mathrm{PbO} \cdot \mathrm{Nb}_{2} \mathrm{O}_{5}$, except that the distortion is of a pseudo-tetragonal rather than a rhombohedral type. The face-centered tetragonal parameters for this phase are $a=10.658 \mathrm{~A}$. $c=10.824 \mathrm{~A}$. As can be seen in the X-ray pattern of table 4 , there are some diffraction peaks which cannot be indexed on the basis of this face-centered cell, but do fit a primitive cell of the same dimen- 
TABLE 4. X-ray diffraction powder data for the compound $3 \mathrm{PbO} \cdot \mathrm{Nb}_{2} \mathrm{O}_{5}\left(\mathrm{CuK}_{\alpha_{1}}\right.$ radiation $)$

\begin{tabular}{|c|c|c|c|c|}
\hline$d$ & $I / I_{0}$ & $1 / d_{\mathrm{obs}}^{2}$ & $1 / d_{\mathrm{calc}}^{2}{ }^{\mathrm{a}}$ & $h k l$ \\
\hline 6.78 & 7 & 0.0217 & & \\
\hline $\begin{array}{l}6.18 \\
5.886\end{array}$ & $\begin{array}{r}16 \\
3\end{array}$ & $\begin{array}{r}.0262 \\
0289\end{array}$ & 0.0262 & 111 \\
\hline 5. 611 & 5 & .0318 & - & \\
\hline & 7 & & .0856 & b 103 \\
\hline 3. 218 & 12 & .0966 & 0966 & 311 \\
\hline 3. 093 & 100 & .1045 & .1046 & 222 \\
\hline 2. 943 & 14 & .1154 & .1144 & b 320 \\
\hline 2.706 & 69 & .1366 & .1366 & 004 \\
\hline 2. 662 & 100 & .1411 & .1408 & 400 \\
\hline 2. 461 & 13 & .1651 & .1649 & 313 \\
\hline 2. 444 & 8 & .1674 & .1670 & 331 \\
\hline $\begin{array}{l}2.404 \\
2.354\end{array}$ & $\begin{array}{l}4 \\
5\end{array}$ & $\begin{array}{l}.1731 \\
.1805\end{array}$ & 1806 & b 214 \\
\hline 2.077 & 4 & $\begin{array}{r}1800 \\
.2319\end{array}$ & $\begin{array}{l}.1800 \\
.2310\end{array}$ & 115 \\
\hline 2. 051 & 8 & .2378 & .2374 & 511 \\
\hline 1. 8989 & 100 & .2773 & .2774 & 404 \\
\hline 1. 8834 & 54 & .2819 & .2817 & 440 \\
\hline 1. 6268 & 58 & $\begin{array}{l}3779 \\
3869\end{array}$ & $\begin{array}{r}3777 \\
3863\end{array}$ & 226 \\
\hline 1. 6091 & 100 & .3862 & .3863 & 622 \\
\hline 1. 5461 & 41 & .4183 & .4183 & 444 \\
\hline 1. 3530 & 8 & .5463 & .5463 & 008 \\
\hline 1. 3323 & 15 & .5634 & .5634 & 800 \\
\hline 1. 2317 & 37 & .6592 & .6594 & 626 \\
\hline $\begin{array}{l}\text { 1. } 2247 \\
\text { 1. } 2224\end{array}$ & $\begin{array}{l}13 \\
13\end{array}$ & $\begin{array}{l}.6667 \\
6692\end{array}$ & .6679 & 662 \\
\hline 1. 2066 & 17 & .6869 & .6871 & 408 \\
\hline 1. 1953 & 17 & .6999 & .6999 & 804 \\
\hline 1.1923 & 18 & .7034 & .7042 & 840 \\
\hline 1. 0991 & 11 & .8278 & .8280 & 448 \\
\hline 1. 0912 & 16 & .8398 & .8408 & 844 \\
\hline 1.0406 & 7 & .9235 & .9240 & $2,2,10$ \\
\hline 1. 0313 & 7 & .9402 & .9411 & 666 \\
\hline 1. 0262 & 16 & .9496 & .9496 & $10,2,2$ \\
\hline
\end{tabular}

a These values are based on a tetragonal unit cell with $a=10.658$ A, $c=10.824 \mathrm{~A}$.

b These peaks are not allowed by a face-centered cell.

sions. However, there are still other $d$-spacings which cannot be indexed at all on this tetragonal cell. Although the pattern is very strongly pseudotetragonal, it must be concluded that the true symmetry is still unknown.

\subsection{Compound $\mathrm{PbO} \cdot 2 \mathrm{Nb}_{2} \mathrm{O}_{5}$}

The compound $\mathrm{PbO} \cdot 2 \mathrm{Nb}_{2} \mathrm{O}_{5}$ has not been previously reported. This new compound can easily be observed by X-ray diffraction studies of specimens of the 1:2 composition, or of compositions between $1: 1$ and $1: 2$, heated in the range in which the rhombohedral form of $\mathrm{PbO} \cdot \mathrm{Nb}_{2} \mathrm{O}_{5}$ would be expected. It was found in the present study to have an X-ray pattern very similar to the orthorhombic and tetragonal forms of $\mathrm{PbO} \cdot \mathrm{Nb}_{2} \mathrm{O}_{5}$. However, there are some lines in the pattern that cannot be indexed on either basis, as shown in table 5. This compound is isostructural with $\mathrm{BaO} \cdot 2 \mathrm{Nb}_{2} \mathrm{O}_{5}$ which also has these extra lines. It must be concluded that the true symmetry of $\mathrm{PbO} \cdot 2 \mathrm{Nb}_{2} \mathrm{O}_{5}$ is, as yet, unknown.

\section{Discussion of Phase Equilibria}

The phase-equilibrium diagram of the binary system $\mathrm{PbO}-\mathrm{Nb}_{2} \mathrm{O}_{5}$ is shown in figure 1. The data from which this diagram has been constructed are given in table 6 . The system contains four
TABLE 5. X-ray diffraction powder data for the compound $\mathrm{PbO} \cdot 2 \mathrm{Nb}_{2} \mathrm{O}_{5}\left(\mathrm{CuK}_{\alpha_{1}}\right.$ radiation $)$

\begin{tabular}{|c|c|c|c|c|c|}
\hline$d$ & $I / I_{0}$ & $h k l$ a & $d$ & $I / I_{0}$ & $h k l^{a}$ \\
\hline $\begin{array}{l}8.84 \\
6.24 \\
5.576 \\
3.948 \\
\text { 3. } 857\end{array}$ & $\begin{array}{r}7 \\
15 \\
15 \\
32 \\
6\end{array}$ & $\begin{array}{l}110 \\
020 \\
120 \\
001\end{array}$ & $\begin{array}{l}2.441 \\
2.313 \\
2.139 \\
2.126 \\
2.073\end{array}$ & $\begin{array}{l}9 \\
4 \\
7 \\
9 \\
6\end{array}$ & $\begin{array}{r}041 \\
250 \\
-350 \\
060\end{array}$ \\
\hline $\begin{array}{l}\text { 3. } 601 \\
\text { 3. } 528 \\
\text { 3. } 455 \\
\text { 3. } 333 \\
\text { 3. } 218\end{array}$ & $\begin{array}{r}5 \\
8 \\
14 \\
16 \\
55\end{array}$ & $\begin{array}{l}230 \\
021 \\
121\end{array}$ & $\begin{array}{l}1.996 \\
1.972 \\
1.858 \\
1.850 \\
1.757\end{array}$ & $\begin{array}{r}5 \\
35 \\
7 \\
5 \\
4\end{array}$ & $\begin{array}{r}260 \\
002 \\
- \\
-451\end{array}$ \\
\hline $\begin{array}{l}\text { 3. } 109 \\
\text { 3. } 067 \\
\text { 3. } 020 \\
\text { 2. } 942 \\
\text { 2. } 861\end{array}$ & $\begin{array}{r}5 \\
8 \\
100 \\
32 \\
5\end{array}$ & $\begin{array}{c}040 \\
140 \\
330 / 221 \\
\end{array}$ & $\begin{array}{l}1.739 \\
\text { 1. } 711 \\
1.681 \\
1.649 \\
1.637\end{array}$ & $\begin{array}{r}4 \\
4 \\
8 \\
16 \\
6\end{array}$ & 142 \\
\hline $\begin{array}{l}2.786 \\
2.627 \\
2.596 \\
2.520\end{array}$ & $\begin{array}{r}60 \\
4 \\
23 \\
4\end{array}$ & $\begin{array}{c}240 / 131 \\
231 \\
\end{array}$ & $\begin{array}{l}\text { 1. } 604 \\
\text { 1. } 508 \\
1.450 \\
1.312\end{array}$ & $\begin{array}{r}15 \\
4 \\
5 \\
7\end{array}$ & $\begin{array}{r}242 \\
-\end{array}$ \\
\hline
\end{tabular}

a The $h k l$ values are given by analogy to the tetragonal structure of high temperature $\mathrm{PbO} \cdot \mathrm{Nb}_{2} \mathrm{O}_{5}$. This is only a pseudo-cell, as there are many peaks which cannot be indexed on this basis. The pseudotetragonal cell has unit-cell parameters of $a=12.44 \mathrm{~A}, c=3.94 \mathrm{~A}$.

congruently melting compounds $5 \mathrm{PbO} \cdot 2 \mathrm{Nb}_{2} \mathrm{O}_{5}$, $2 \mathrm{PbO} \cdot \mathrm{Nb}_{2} \mathrm{O}_{5}, \mathrm{PbO} \cdot \mathrm{Nb}_{2} \mathrm{O}_{5}$, and $\mathrm{PbO} \cdot 2 \mathrm{Nb}_{2} \mathrm{O}_{5}$; and two incongruently melting compounds $3 \mathrm{PbO} \cdot \mathrm{Nb}_{2} \mathrm{O}_{5}$ and $3 \mathrm{PbO} \cdot 2 \mathrm{Nb}_{2} \mathrm{O}_{5}$.

$\mathrm{PbO}$ has been accepted as melting at $883 \pm 5^{\circ} \mathrm{C}$ [20]. There is an eutectic between $\mathrm{PbO}$ and $3 \mathrm{PbO}$. $\mathrm{Nb}_{2} \mathrm{O}_{5}$ at approximately 94 mole percent of $\mathrm{PbO}$ and $835^{\circ} \mathrm{C}$. The eutectic temperature was located by X-ray diffraction analyses of quenched specimens from sealed $\mathrm{Pt}$ tubes (see section 5). When a specimen in the two-phase region was quenched from below the solidus, yellow $\mathrm{PbO}$ and $3 \mathrm{PbO} \cdot \mathrm{Nb}_{2} \mathrm{O}_{5}$ were found to coexist. Changes in $d$-spacings of the X-ray patterns indicate that a small amount of solid solution, less than 2 mole percent, probably exists in the yellow $\mathrm{PbO}$ phase.

The compound $3 \mathrm{PbO} \cdot \mathrm{Nb}_{2} \mathrm{O}_{5}$ was found to melt incongruently to $5 \mathrm{PbO} \cdot 2 \mathrm{Nb}_{2} \mathrm{O}_{5}$ plus liquid at $985^{\circ} \mathrm{C}$. Specimens containing 75 mole percent of $\mathrm{PbO}$, in a sealed Pt tube, quenched from below this temperature showed only the compound $3 \mathrm{PbO} \cdot \mathrm{Nb}_{2} \mathrm{O}_{5}$. Specimens of the same composition quenched from just above this temperature showed some of the compound $5 \mathrm{PbO} \cdot 2 \mathrm{Nb}_{2} \mathrm{O}_{5}$. The compound $5 \mathrm{PbO} \cdot 2 \mathrm{Nb}_{2} \mathrm{O}_{5}$ is essentially isostructural with $2 \mathrm{PbO} \cdot \mathrm{Nb}_{2} \mathrm{O}_{5}$, and there is apparently complete solid solution between the two. The compound $5 \mathrm{PbO} \cdot 2 \mathrm{Nb}_{2} \mathrm{O}_{5}$ appears to melt congruently at approximately $1,220^{\circ} \mathrm{C}$. There may be a very small eutectic or minimum in the solid-solution area close to the 5-2 compound or this compound might actually melt incongruently; however, any such discrepancies from the situation shown in figure 1 are so small as to be undetectable with the present experimental equipment.

The compound $2 \mathrm{PbO} \cdot \mathrm{Nb}_{2} \mathrm{O}_{5}$ was observed to melt congruently at about $1,233^{\circ} \mathrm{C}$. Specimens sealed in a Pt tube and quenched from below this temperature showed no sign of melting. Above this temperature, the specimen appeared to be completely melted. 


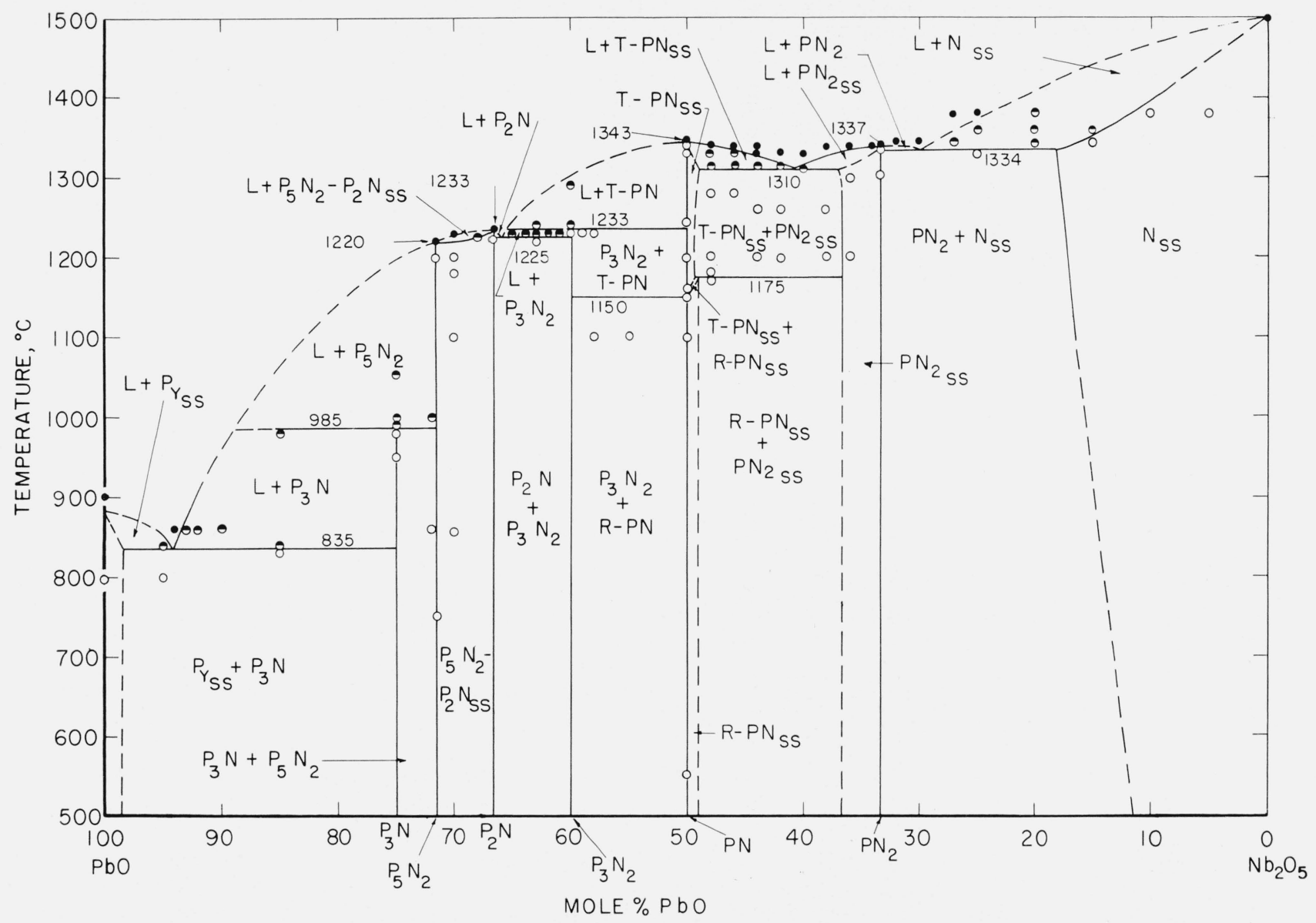

Figure 1. Phase equilibrium diagram for the system $\mathrm{PbO}-\mathrm{Nb}_{2} \mathrm{O}_{5}$.

$\mathrm{P}_{\mathbf{y}}$-yellow PbO, orthorhombic; $\mathrm{P}_{3} \mathrm{~N}-3 \mathrm{PbO} \cdot \mathrm{Nb}_{2} \mathrm{O}_{5} ; \mathrm{P}_{5} \mathrm{~N}_{2}-5 \mathrm{PbO} \cdot 2 \mathrm{Nb}_{2} \mathrm{O}_{5} ; \mathrm{P}_{2} \mathrm{~N}-2 \mathrm{PbO} \cdot \mathrm{Nb}_{2} \mathrm{O}_{5} ; \mathrm{P}_{3} \mathrm{~N}_{2}-3 \mathrm{PbO} \cdot 2 \mathrm{Nb}_{2} \mathrm{O}_{5} ; \mathrm{T}-\mathrm{PN}-$ tetragonal $\mathrm{PbO} \cdot \mathrm{Nb}_{2} \mathrm{O}_{5} ; \mathrm{R}-\mathrm{PN}-\mathrm{rhom}$ bohedral $\mathrm{PbO} \cdot \mathrm{Nb}_{2} \mathrm{O}_{5} ; \mathrm{PN}_{2}-\mathrm{PbO} \cdot 2 \mathrm{Nb}_{2} \mathrm{O}_{5} ; \mathrm{N}-\mathrm{Nb}_{2} \mathrm{O}_{5} ; \mathrm{SS}$ - solid solution; $\mathrm{O}$-no melting; $\bullet$-partial melting; - completely melted.

No phase other than that of $2 \mathrm{PbO} \cdot \mathrm{Nb}_{2} \mathrm{O}_{5}$ was observed in the X-ray pattern of a quenched specimen of the melted material, thus strongly indicating congruent melting.

Compositions between $2 \mathrm{PbO} \cdot \mathrm{Nb}_{2} \mathrm{O}_{5}$ and $\mathrm{PbO} \cdot \mathrm{Nb}_{2} \mathrm{O}_{5}$ give conflicting data when examined as quenched specimens from sealed tubes and as ceramic pellets heated in air. Cook and Jaffe [4] observed a singlephase cubic pyrochlore-type structure at a composition corresponding to " $\mathrm{Pb}_{1.5} \mathrm{Nb}_{2} \mathrm{O}_{6.5}$ " or 60 mole percent of $\mathrm{PbO}$. This observation was confirmed in the present study for both air and sealed-tube techniques. However, Cook [21] has stated that in "a closely spaced series of compositions between $\mathrm{Pb}_{2^{-}}$ $\mathrm{Nb}_{2} \mathrm{O}_{7}$ and $\mathrm{Pb}_{1,5} \mathrm{Nb}_{2} \mathrm{O}_{6.5} \ldots$. extra lines of the rhombohedral splitting do not draw closer to the main lines of the pattern, as you would expect. They just fade out." A similar phenomena was observed in the present study for specimens prepared at 1-mole-percent intervals between 65 and 60 mole percent of $\mathrm{PbO}$, when heated in covered $\mathrm{Pt}$ crucibles.
When these specimens were quenched in sealed Pt tubes a clear picture of a two-phase region with little or no solid solution was observed for temperatures of $1,220^{\circ} \mathrm{C}$ or below. At $1,230^{\circ} \mathrm{C}$ the cubic $3 \mathrm{PbO} \cdot 2 \mathrm{Nb}_{2} \mathrm{O}_{5}$ phase greatly predominated throughout all the specimens from 65 to 61 mole percent of $\mathrm{PbO}$. The rhombohedral $2 \mathrm{PbO} \cdot \mathrm{Nb}_{2} \mathrm{O}_{5}$ phase was found to coat the walls of the Pt tube and was difficult to recover, thus indicating that this phase had been in the vapor state and that these specimens had been above the eutectic temperature. The eutectic composition could not be located exactly but is probably close to 66 percent of $\mathrm{PbO}$. The eutectic temperature was thus located at $1,225 \pm 5^{\circ} \mathrm{C}$. In the sealed tube, the composition containing 60 mole percent of $\mathrm{PbO}$ was found to melt incongruently at $1,233^{\circ} \mathrm{C}$, forming some $\mathrm{PbO} \cdot \mathrm{Nb}_{2} \mathrm{O}_{5}$. Compositions of 59 and 58 mole percent of $\mathrm{PbO}$ contained both cubic $3 \mathrm{PbO} \cdot 2 \mathrm{Nb}_{2} \mathrm{O}_{5}$ and $\mathrm{PbO} \cdot \mathrm{Nb}_{2} \mathrm{O}_{5}$ when quenched in the sealed tube from below the solidus. Therefore, a compound of the ratio $3 \mathrm{PbO} \cdot 2 \mathrm{Nb}_{2} \mathrm{O}_{5}$ has been fully established. 
TABLE 6. Experimental data for compositions in the binary system $\mathrm{PbO}-\mathrm{Nb}_{2} \mathrm{O}_{5}$

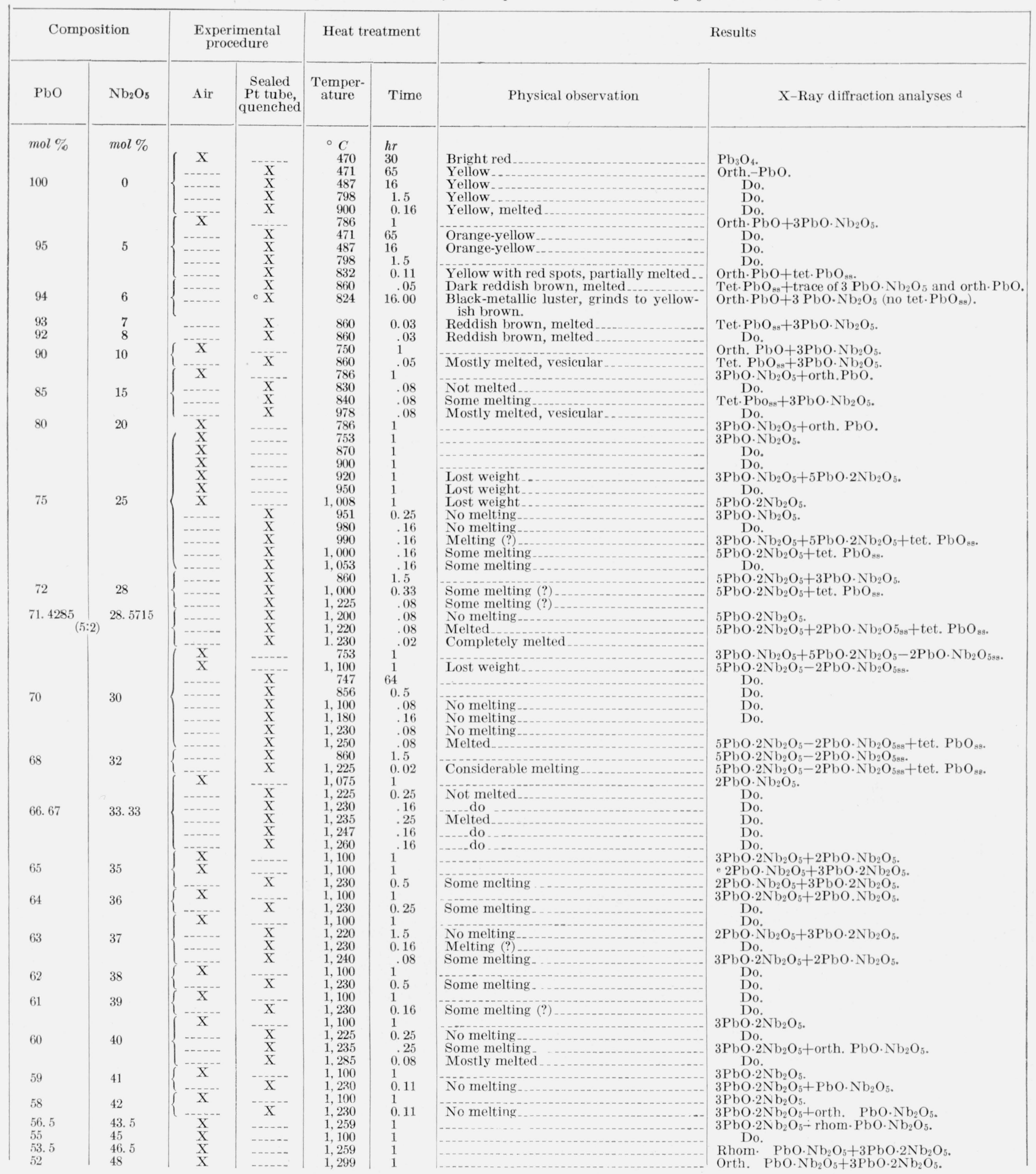


TABLE 6. Experimental data for compositions in the binary system $\mathrm{PbO}-\mathrm{Nb}_{2} \mathrm{O}_{5}-\mathrm{Continued}$

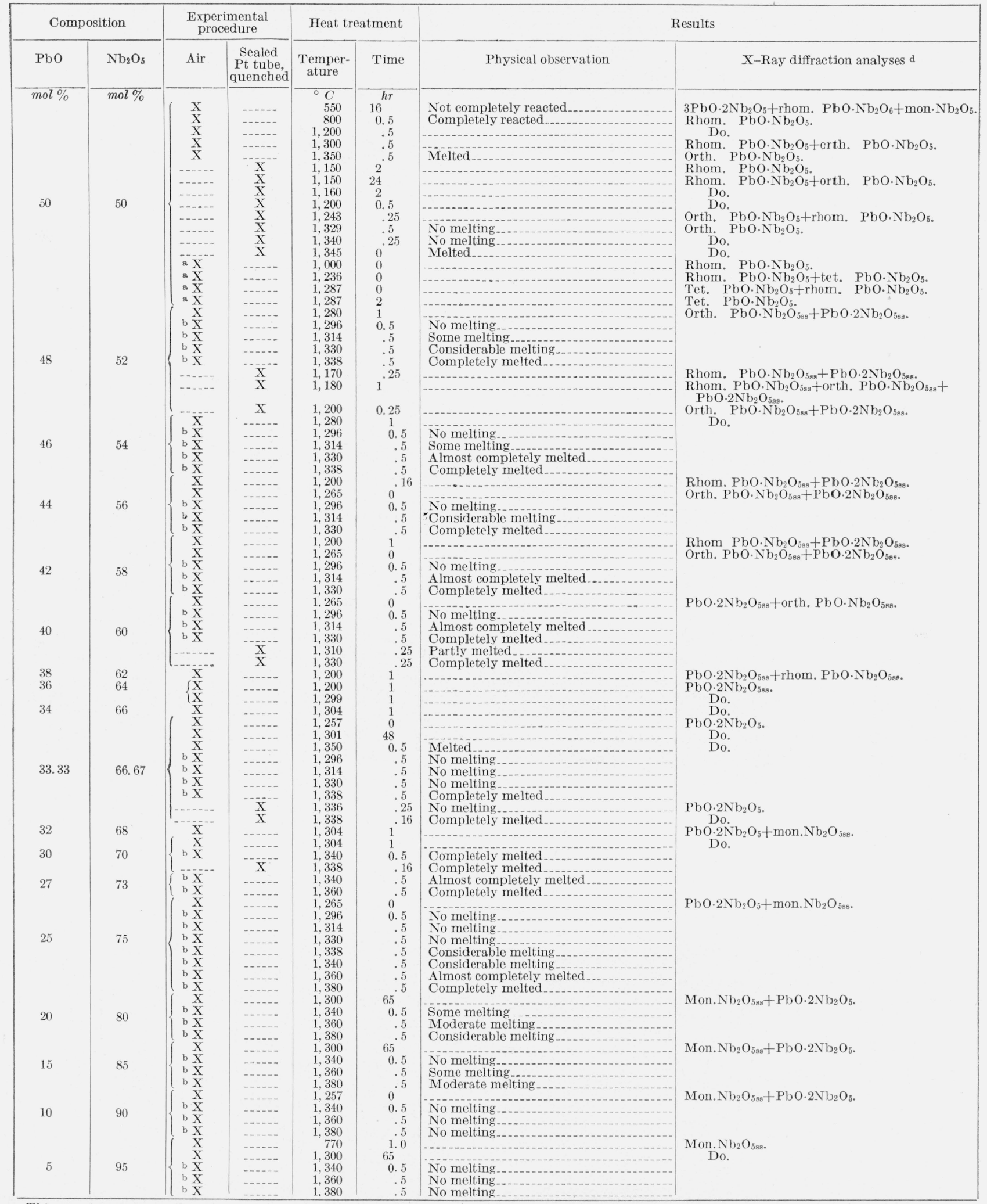

a This experiment was conducted in a high-temperature $\mathrm{X}$-ray furnace. b The specimens had been ground into the shape of four-sided-grooved pyramids.

mids. mine if equilibrium could be obtained from the nonequilibrium tetragonal $\mathrm{PbO}$ solid solution. $\mathrm{d}$ The phases identified are given in the order of the amount present at room temperature. The phases are not necessarily those present at the temperature to which the specimen was heated: Mon.-monoclinic; orth--orthorhombic; tet.tetragonal; rhom.-rhombohedral; ss-solid solution.

e This X-ray pattern was made on the same specimen as preceding after grind- 
The compound $\mathrm{PbO} \cdot \mathrm{Nb}_{2} \mathrm{O}_{5}$ was found to melt congruently at $1,343 \pm 2^{\circ} \mathrm{C}$ by both the sealed-Pttube method and the grooved-pyramid method. However, the temperature of the rhombohedraltetragonal phase transformation could not be arrived at by heating in air. It appears that this phase transformation is quite sluggish. High-temperature X-ray patterns in air show that several hours at $1,287^{\circ} \mathrm{C}$ are required to convert all of the low-temperature rhombohedral form to the high-temperature tetragonal form. A specimen heated at $1,200^{\circ} \mathrm{C}$ for $1 \mathrm{hr}$ in air and examined at room temperature showed only the low-temperature form. However, the same material heated in a sealed $\mathrm{Pt}$ tube for 30 min at $1,200^{\circ} \mathrm{C}$ was converted in part to the hightemperature form. A 2-hr heat treatment as low as $1,160^{\circ} \mathrm{C}$ gave some of the high-temperature form while the same time at $1,150^{\circ} \mathrm{C}$ gave only low-temperature $\mathrm{PbO} \cdot \mathrm{Nb}_{2} \mathrm{O}_{5}$. However, holding the $1: 1$ composition at $1,150^{\circ} \mathrm{C}$ for $24 \mathrm{hr}$ did convert a small amount of the material to the high-temperature form. It seems that a maximum temperature of $1,150^{\circ} \mathrm{C}$ is as close to the transformation temperature as can be obtained in reasonable laboratory time.

$\mathrm{PbO} \cdot \mathrm{Nb}_{2} \mathrm{O}_{5}$ will accept a small amount of $\mathrm{Nb}_{2} \mathrm{O}_{5}$ into solid solution as shown by significant changes in $d$-spacings of the X-ray patterns. However, the composition containing 48 mole percent of $\mathrm{PbO}$ has two phases, indicating that solid solution is less than 2 mole percent. This small amount of solid solution is enough to raise the temperature of the phase transformation from the rhombohedral to the tetragonal form by about $25^{\circ} \mathrm{C}$, as shown by quenching experiments in sealed $\mathrm{Pt}$ tubes.

A eutectic exists between $\mathrm{PbO} \cdot \mathrm{Nb}_{2} \mathrm{O}_{5}$ and $\mathrm{PbO}$. $2 \mathrm{Nb}_{2} \mathrm{O}_{5}$ at about 41 mole percent of $\mathrm{PbO}$ and $1,310^{\circ} \mathrm{C}$. This eutectic was found by the grooved-pyramid technique and checked with experiments using sealed $\mathrm{Pt}$ tubes. The compound $\mathrm{PbO} \cdot 2 \mathrm{Nb}_{2} \mathrm{O}_{5}$ was found to melt, probably congruently, at $1,337^{\circ} \pm 2^{\circ} \mathrm{C}$. $\mathrm{PbO} \cdot 2 \mathrm{Nb}_{2} \mathrm{O}_{5}$ takes more than 2 but less than 4 mole percent of $\mathrm{PbO}$ into solid solution at the solidus temperature. This solid solution is retained on relatively slow cooling, as shown by X-ray patterns of specimens containing 36 and 38 mole percent of $\mathrm{PbO}$.

Although $\mathrm{PbO} \cdot 2 \mathrm{Nb}_{2} \mathrm{O}_{5}$ appears to melt sharply, no eutectic has been definitely located on the high $\mathrm{Nb}_{2} \mathrm{O}_{5}$ side. However, some melting-point data of the compositions containing 32 and 30 mole percent of $\mathrm{PbO}$ indicate a eutectic in this region. Both of these compositions appear completely melted, by the pyramid method, at $1,344^{\circ} \mathrm{C}$. If the $1: 2 \mathrm{com}$ pound melted incongruently, these specimens would be only partially melted at $1,344^{\circ} \mathrm{C}$. A eutectic can, therefore, be placed at about 30 mole percent of $\mathrm{PbO}$ and $1,334 \pm 4^{\circ} \mathrm{C}$.

$\mathrm{Nb}_{2} \mathrm{O}_{5}$ is found to accept a little over 15 mole percent of $\mathrm{PbO}$ into solid solution at the eutectic temperature. As shown by X-ray diffraction this amount decreases to a little less than 10 mole percent at room temperature. The addition of $\mathrm{PbO}$ to $\mathrm{Nb}_{2} \mathrm{O}_{5}$ seems to lower the temperature of the phase transformation from the low to the high form of $\mathrm{Nb}_{2} \mathrm{O}_{5}$. The specimen containing 5 mole percent of $\mathrm{PbO}$ heated to $770^{\circ} \mathrm{C}$ for $1 \mathrm{hr}$ contained only the high-temperature form of $\mathrm{Nb}_{2} \mathrm{O}_{5}$. This form was also found in the nonequilibrium assemblage of the $50: 50$ specimen at $550^{\circ} \mathrm{C}$ for $16 \mathrm{hr}$. No attempt has been made to locate accurately the temperature of this phase transformation in the presence of $\mathrm{PbO}$. The low temperature form of $\mathrm{Nb}_{2} \mathrm{O}_{5}$ has notbeen indicated on the phase diagram of figure 1 as it seems likely that this polymorph is only metastable and has no true equilibrium position in the binary system. The melting point of $\mathrm{Nb}_{2} \mathrm{O}_{5}$ was accepted as $1,500 \pm 10^{\circ} \mathrm{C}$ as found by Roth and Coughanour $[22]$.

\section{Occurrence of a Nonequilibrium Red $\mathrm{PbO}$ Solid Solution}

When specimens of composition between pure $\mathrm{PbO}$ and the 2:1 compound are quenched from above the solidus, a phase similar to the tetragonal red $\mathrm{PbO}$ is observed in the $\mathrm{X}$-ray patterns. This phase has an a parameter about the same as pure tetragonal $\mathrm{PbO}$ but a $c$ parameter which is much larger. This $c$ parameter is always approximately the same, regardless of the temperature or composition of the quenched specimen. It has a value of about $5.08 \mathrm{~A}$ as compared to the value of $5.023 \mathrm{~A}$ for pure $\mathrm{PbO}$. Specimens containing 95 percent of $\mathrm{PbO}$ consisted only of yellow $\mathrm{PbO}$ and this red $\mathrm{PbO}$ solid solution, when quenched from above the solidus. When the composition is on the high- $\mathrm{Nb}_{2} \mathrm{O}_{5}$ side of the eutectic, the tetragonal solid solution occurs with the compound $3 \mathrm{PbO} \cdot \mathrm{Nb}_{2} \mathrm{O}_{5}$. When specimens of $3 \mathrm{PbO} \cdot \mathrm{Nb}_{2} \mathrm{O}_{5}$ are heated above the incongruent melting point, about $985^{\circ} \mathrm{C}$, this tetragonal phase is observed to occur with the $5 \mathrm{PbO} \cdot 2 \mathrm{Nb}_{2} \mathrm{O}_{5}$ compound. Specimens of the $5: 2$ compound and compositions between $5: 2$ and $2: 1$ contain, upon quenching from above the solidus, red $\mathrm{PbO}$ solid solution plus a rhombohedral pyrochlore-type solid solution.

A specimen of the eutectic composition, 94 mole percent of $\mathrm{PbO}$, showed almost entirely the red $\mathrm{PbO}$ solid solution when quenched from above the melting point. This specimen was put back in a sealed Pt tube and held overnight just below the melting point. The resulting product was an equilibrium mixture of yellow $\mathrm{PbO}$ and the compound $3 \mathrm{PbO} \cdot \mathrm{Nb}_{2} \mathrm{O}_{5}$. Thus the red $\mathrm{PbO}$ solid solution has been proven to be metastable.

There are several possible explanations of this nonequilibrium phenomenon. The most obvious conclusion would be that oxidation of $\mathrm{PbO}$ and reduction of $\mathrm{Nb}_{2} \mathrm{O}_{5}$ occur when they are heated together in a closed tube. However, this oxygen solid solution would then have parameters depending upon the amount of $\mathrm{Nb}_{2} \mathrm{O}_{5}$ present, which is not observed to be the case. Another possibility is that the tetragonal $\mathrm{PbO}$ solid solution represents the composition of the liquid in equilibrium at the temperature from which the material was quenched. 
That is, the liquid when quenched devitrifies into a single-phase crystalline solid of the same composition. However, this explanation also would require different parameters of the solid solution for different temperatures and compositions. An alternative hypothesis is that the phase does not represent the equilibrium liquid but that the liquid follows its regular course of crystallization until it reaches the eutectic composition. This composition then crystallizes out as a single-phase nonequilibrium solid solution, having a structure similar to the lowtemperature form of $\mathrm{PbO}$.

It does not seem likely that this solid solution is of the substitutional type. The radius of $\mathrm{Pb}^{+2}$ is $1.20 \mathrm{~A}$ and that of $\mathrm{Nb}^{+5}$ is $0.69 \mathrm{~A} \mathrm{[23].} \mathrm{The} \mathrm{ratio}$ between the two is well beyond the limit at which even partial substitution might be expected. Therefore, it must be concluded that this nonequilibrium solid solution is of an interstitial type.

There is also the possibility that this apparent red $\mathrm{PbO}$ solid solution is a true compound in the system, having a minimum thermal stability at the temperature indicated here for the eutectic temperature, $835^{\circ} \mathrm{C}$, and a composition equal to the hypothesized eutectic composition. That such a compound should have the same structure as red $\mathrm{PbO}$ seems highly unlikely and is not considered to be the true explanation of the observed phenomena.

\section{Summary}

The system $\mathrm{PbO}-\mathrm{Nb}_{2} \mathrm{O}_{5}$ was studied by means of solid-state reactions, fusion characteristics, and X-ray diffraction data. The existence of six compounds in this system was shown. They are $3 \mathrm{PbO} \cdot \mathrm{Nb}_{2} \mathrm{O}_{5}$ which melts incongruently at about $985^{\circ} \mathrm{C}, 5 \mathrm{PbO} \cdot 2 \mathrm{Nb}_{2} \mathrm{O}_{5}$ which melts congruently at $1,220^{\circ} \mathrm{C}, 2 \mathrm{PbO} \cdot \mathrm{Nb}_{2} \mathrm{O}_{5}$ which melts congruently at about $1,233^{\circ} \mathrm{C}, 3 \mathrm{PbO} \cdot 2 \mathrm{Nb}_{2} \mathrm{O}_{5}$ which melts incongruently at about $1,233^{\circ} \mathrm{C}, \mathrm{PbO} \cdot \mathrm{Nb}_{2} \mathrm{O}_{5}$ which melts congruently at about $1,343^{\circ} \mathrm{C}$, and $\mathrm{PbO} \cdot 2 \mathrm{Nb}_{2} \mathrm{O}_{5}$ which melts congruently at about $1,337^{\circ} \mathrm{C}$. The four eutectic points are located as follows: about 94 mole percent of $\mathrm{PbO}$ and $835^{\circ} \mathrm{C}$, about 66 mole percent of $\mathrm{PbO}$ and $1,225^{\circ} \mathrm{C}, 41$ mole percent of $\mathrm{PbO}$ and $1,310^{\circ} \mathrm{C}$, and about 30 mole percent of $\mathrm{PbO}$ and $1,334^{\circ} \mathrm{C}$.

Complete solid solution was noted between $2 \mathrm{PbO} \cdot \mathrm{Nb}_{2} \mathrm{O}_{5}$ and $5 \mathrm{PbO} \cdot 2 \mathrm{Nb}_{2} \mathrm{O}_{5}$. Partial solid solution occurred between the two compounds $\mathrm{PbO} \cdot \mathrm{Nb}_{2} \mathrm{O}_{5}$ and $\mathrm{PbO} \cdot 2 \mathrm{Nb}_{2} \mathrm{O}_{5}$. $\quad \mathrm{Nb}_{2} \mathrm{O}_{5}$ accepts about 15 mole percent $\mathrm{PbO}$ in solid solution at the eutectic temperature. No solid solution occurs on either side of the compound $3 \mathrm{PbO} \cdot 2 \mathrm{Nb}_{2} \mathrm{O}_{5}$.
The rhombohedral-tetragonal inversion of $\mathrm{PbO} \cdot \mathrm{Nb}_{2} \mathrm{O}_{5}$ was found to take place very sluggishly at approximately $1,150^{\circ} \mathrm{C}$ in a sealed $\mathrm{Pt}$ tube. The temperature of this phase transition is raised by the $\mathrm{Nb}_{2} \mathrm{O}_{5}$ solid solution to about $1,175^{\circ} \mathrm{C}$.

A recent paper by M. H. Francombe and B. Lewis [24] suggests a solid-solution region from $\mathrm{PbO}: 1.5 \mathrm{Nb}_{2} \mathrm{O}_{5}$ to $\mathrm{PbO}: 3 \mathrm{Nb}_{2} \mathrm{O}_{5}$. This covers a range in which two phases have been found, for the most part, in the present work. No explanation can be found for the observation of such a large amount of solid solution in the $\mathrm{PbO}-\mathrm{Nb}_{2} \mathrm{O}_{5}$ system.

The assistance of Charles $\mathrm{R}$. Drew in preparing and heating most of the specimens is gratefully acknowledged. John M. Cerceo assisted in the measurements of some of the X-ray data. Many helpful suggestions were received from Carl $R$. Robbins and Ernest M. Levin.

\section{References}

[1] G. Goodman, J. Am. Ceram. Soc. 36, 368 (1953).

[2] M. H. Francombe, Acta Cryst. 9, 683 (1956).

[3] W. R. Cook, Jr., and H. Jaffe, Phys. Rev. 88, 1426 (1952).

[4] W. R. Cook, Jr., and H. Jaffe, Phys. Rev. 89, 12 y7 (1953)

[5] B. Jaffe, R. S. Roth, and S. Marzullo, J. Research N BS 55, 239 (1955) R P2626.

[6] R. F. Geller, P. J. Yavorsky, B. L. Steierman, and A. S. Creamer, J. Research NBS 36, 277 (1946) RP1703.

[7] G. Brauer, Z. anorg. u. allgem. Chem. 248, 1 (1941).

[8] F. Holzberg, A. Reisman, M. Berry, and M. Berkenblit, J. Am. Chem. Soc. 79, 2039 (1957).

[9] A. Magneli and S. Lagergren, ASTM Index of X-ray Diffraction Data, Card No. 5-0379.

[10] F. Holzberg, Private communication.

[11] H. E. Swanson and R. K. Fuyat, NBS Circ. 539, Vol. II (1953).

[12] M. Petersen, J. Am. Chem. Soc. 63, 2617 (1941).

[13] A. F. Efimov, V. A. Pchelkin, Yu. P. Simanov, E. P. Artamanova, and A. V. Lapitskii, Vestnik Moskov. Univ. 9, No. 6, Ser. Fiz. Mat. i. Estestven Nauk No. 4, 77 (1954).

[14] R. S. Roth, Acta Cryst. 10, 437 (1957).

[15] W. R. Cook, Bull. Am. Ceram. Soc. 3\%, No. 4, Program, 33 (1958).

[16] W. R. Cook, Private communication.

[17] G. Shirane and R. Pepinsky, Phys. Rev. 92, 504 (1953).

[18] J. K. Hulm, Phys. Rev. 92, 504 (1953).

[19] F. Jong, G. Shirane, and R. Pepinsky, Phys. Rev. 98, 903 (1955).

[20] R. F. Geller, A. S. Creamer, and E. N. Bunting, J. Research NBS 13, 237 (1934) RP705.

[21] W. R. Cook, Private communication.

[22] R. S. Roth and L. W. Coughanour, J. Research NBS 55, 209 (1955) RP2621.

[23] L. H. Ahrens, Geochim. Cosmochim. Acta 2, 155 (1952).

[24] M. H. Francombe and B. Lewis, Acta Cryst. 11, 696 (1958).

Washington, July 11, 1958. 